\title{
Heavy Metals Accumulation in the Edible Parts of some Sewage Wastewater Irrigated Vegetable Crops
}

\author{
Nadia M. K. Roshdy
}

Department of Soils and Water, Faculty of Agriculture, Assiut University, Assiut 71526, Egypt Received on: 4/1/2018 Accepted for publication on: 16/1/2018

\begin{abstract}
Nowadays, using sewage wastewater in the irrigated agriculture causes hazardous environment impacts. Assessment of these negative effects is vital issue to prevent heavy metals to be introduced in the food chain. Field and laboratory studies were conducted at Ellwan, Mangabad and El-Madabegh villages, Assiut Governorate, in order to evaluate heavy metals concentrations in the edible parts of carrot, turnip and onion plantswhich were irrigated with sewage water (SW). The obtained results indicated that, the soils of the studied villages were contaminated by heavy metals. The concentrations of $\mathrm{Zn}, \mathrm{Cu}, \mathrm{Pb}, \mathrm{Cd}$ and $\mathrm{Ni}$ concentrations in the edible portion of thesevegetables plants ranged between 45-70, 13 $19,3.8-6.2,2.85-3.85$ and $2-6 \mathrm{mgkg}^{-1}$, respectively. The obtained results showed that the concentrations of $\mathrm{Pb}, \mathrm{Cd}$ and $\mathrm{Ni}$ in the edible plants were higher than the permissible limit levels but those of $\mathrm{Zn}$ and $\mathrm{Cu}$ were within the safe limit levels. It is worthy to mention that the irrigated edible vegetable crops especially onion, turnip and carrot with SW should be avoided. This study highlights the potential hazard for human health due to uptake of high concentrations of heavy metals especially $\mathrm{Ni}, \mathrm{Cd}$ and $\mathrm{Pb}$ by the studied vegetable crops.
\end{abstract}

Keywords: Contaminated soils, Safe limits, Human consumption, Heavy metals, Carrot, Turnip, Onion.

\section{Introduction}

Water is important for all human activities. Water accounted for about $50-97 \%$ of plant and animal bodies; moreover, it is a vital for all biological processes in plant and animal cells (Buchholz, 1993). Fresh water recourses in the world are very limited and only $0.6 \%$ of the total world water resources is fresh water (FAO, 2015). Fresh water resources have been decreased in an alarming rate and they may not able to meet the requirements of the different human in the future (Qadir et al., 2007). The agriculture sectored uses about $80 \%$ of the water resources in irrigation purposes. Some of agriculture lands located near urbanare irrigated by wastewater because of the low availability of fresh water for crop production (Qadir et al., 2007).

The increasing of population and human activities enlarged the volume of sewage wastewaters (SW) (Qadir et al., 2007; Ismail et al., 2014). In many developing countries, these water resourcesmay, in most cases, use in the form of diluted raw sewage, even if it is considered illegally (Qadir et al., 2007). Wastewatersquality differs both between and within countries. In many poor countries in Africa, Asia and Latin America, the untreated wastewaters are used widdly in agriculture production, while in middle-income countries treated wastewater is used (Qadir et al., 2007; Ismail et al., 2014). 
The use of sewage wastewater in irrigation provides the soil with nutrients and organic matter; moreover, it is an inexpensive system for wastewater disposal (Ullah et al., 2011; Gosh et al., 2012). In many situations, Egyptian farmers use wastewater in irrigation even when the fresh one is available, due to the high profits earned by using waste water. Sewage wastewaters (SW) are usually rich in nitrogen $(\mathrm{N})$, phosphorus $(\mathrm{P})$ and potassium $(\mathrm{K})$ and farmers usethese waters as a low price fertilizers (Chhabra, 1989). Nutrient concentrations in sewage waste waters are varied widely and Chhabra (1989) in India found that the SW contained 48.3, 7.6, 72.4 and $34.6 \mathrm{mg}$ $\mathrm{L}^{-1}$ of $\mathrm{N}, \mathrm{P}, \mathrm{K}$ and $\mathrm{S}$, respectively besides micro-nutrients contents of $0.34,10.8,0.2$ and $0.36 \mathrm{mgL}^{-1}$ for $\mathrm{Zn}$, $\mathrm{Fe}, \mathrm{Cu}$ and $\mathrm{Mn}$, respectively. Therefore, ten SW irrigations of $7.5 \mathrm{~cm}$ each could add about 362, 58, 540 and $260 \mathrm{~kg} \mathrm{ha}^{-1}$ of $\mathrm{N}, \mathrm{P}, \mathrm{K}$ and $\mathrm{S}$, respectively, to the soil which aremore than the nutrient requirements of most crops (Eissa, 2016). These findings recapitulate that wastewater hasa great potential as a manure when it is used to irrigate crops (Khurana and Singh, 2012).

Wastewaters contain high levels of $\mathrm{Cd}, \mathrm{Pb}, \mathrm{Cr}$ and As which are not essential for plant and animal nutrition (Kanwar and Sandha, 2000). The use ofsewage wastewater can in the irrigation processes may cause remarkable increases in soil heavy metal concentrations (Khan et al., 2008; Ullah et al., 2011; Gosh et al., 2012). The raising of soil heavy metal content will lead to introduce the metals to the vegetables and cereals crops causing a potential health risk to human and animal (Sharma et al., 2006; Singh et al., 2010; Gupta et al., 2011). The concentrations of heavy metalsin plants cultivated on wastewater-irrigated soils are significantly higher than in those grown on fresh water-irrigated ones (Khan et al., 2008; Singh et al., 2010; Gupta et al., 2011).

The use of sewage wastewater to irrigate plants is an old action in many areas in Egypt due to the complexity of its treatment and disposal as well as the scarcity of fresh irrigation water. Its use is obligatory in order to provide foods to the everincreasing population. It may cause soils and plants to be contaminated with heavy metals. The present study was undertaken to assess heavy metal contents of carrot, turnip and onion plants irrigated with sewage wastewater.

\section{Materials and Methods \\ Site Description and Sampling}

Composite plant samplesof carrot, turnip and onion crops irrigated with sewage waste water were collected from Ellwan, Mankabad and Arab Elmadabegh villages, Assiut governorate, Egypt whichare located at $27^{\circ} 12^{-} 16.67^{=} \mathrm{N}$ latitude and $31^{\circ}$ $09^{-} 36.86^{=} \mathrm{E}$ longitude to evaluate levels of some heavy metals $(\mathrm{Zn}, \mathrm{Cu}$, $\mathrm{Pb}, \mathrm{Ni}$ and $\mathrm{Cd}$ ) in these vegetables plants. The soils in these villageshave been irrigated by raw sewage water for more than 50 years. Table 1 shows the main soil properties of the studied site. Each composite sample included the edible portion of ten plants of each crop. Theplant samples were washed twice by tap water, rinsed by distilled water, air-dried, 
oven-dried at $70^{\circ} \mathrm{C}$ to a constant weight, groundand then were kept for chemical analysis. Soil $(0-20 \mathrm{~cm})$ and sewage wastewater samples were also taken from each study site.

Table 1. Some physical and chemical characteristics of the soils in the studied sites

\begin{tabular}{|l|c|c|c|}
\hline \multicolumn{1}{|c|}{ Soil property } & Ellwan & Mankhabad & Arab-Elmadabegh \\
\hline Clay $(\mathrm{gkg})$ & 100 & 120 & 110 \\
\hline Silt $(\mathrm{g} k \mathrm{~kg})$ & 200 & 180 & 190 \\
\hline Sand $(\mathrm{g} k \mathrm{~kg})$ & 700 & 700 & 700 \\
\hline Texture & Sandy loam & Sandy loam & Sandy loam \\
\hline $\mathrm{CaCO}_{3}(\mathrm{~g} / \mathrm{kg})$ & 62 & 75 & 58 \\
\hline $\mathrm{pH}(1: 2)$ & 7.43 & 7.44 & 7.45 \\
\hline CEC $(\mathrm{cmohkg})$ & 18 & 22 & 17 \\
\hline Total organic C $(\mathrm{gkg})$ & 5.2 & 5.1 & 5.8 \\
\hline EC $(1: 2)(\mathrm{dS} / \mathrm{m})$ & 1.5 & 1.6 & 1.5 \\
\hline
\end{tabular}

\section{Soil, water and plant analysis}

The physical and chemical properties of the studied soil samples were determined according to Burt (2004) as they are shown in Table 1. The available heavy metals $(\mathrm{Zn}, \mathrm{Cu}$, $\mathrm{Pb}, \mathrm{Cd}$ and $\mathrm{Ni}$ ) were extracted from the soil samples using a $0.005 \mathrm{M}$ DTPA (diethylen triamine penta acetic acid) solution buffered at $\mathrm{pH} 7.3$ as described by Lindsay and Norvell (1978). To determine the total heavy metals, the soil samples were digested according to the procedure given by the US EPA (1996). A known volume of each sewage wastewater samplewas oven-dried and then was digested using concentrated $\mathrm{HNO}_{3}$ at $80{ }^{\circ} \mathrm{C}$ (Table 2). The soil samples were air-dried and sieved with a 2-mm diameter sieve and kept for analysis. The metals in the soil, water and plant digest as well as DTPA soil extract were measured using the Inductivity Coupled Plasma Emission Optical Emission Spectrometry (ICP-OES thermo iCAP 6000 series). The ground plant samples were digested using concentrated acidsof $\mathrm{HNO}_{3}$ and $\mathrm{HClO}_{4}$.

\subsection{Statistical analysis}

One-way ANOVA was used to test the significance of different between the studied plants and Duncan test was used to compare between means. The collected data were statically analyzed using SPSS statistical software.

Table 2. Chemical analysis of the irrigation sewage wastewater in the studied sites

\begin{tabular}{|l|c|c|c|c|c|c|c|}
\hline \multirow{2}{*}{\multicolumn{1}{c|}{ Site }} & \multirow{2}{*}{$\mathbf{p H}$} & $\mathbf{E C}$ & $\mathbf{Z n}$ & $\mathbf{C u}$ & $\mathbf{P b}$ & $\mathbf{C d}$ & Ni \\
\cline { 4 - 8 } & & $\left(\mathrm{dS} \mathrm{m}^{-1}\right)$ & \multicolumn{5}{|c|}{$\left(\mathrm{mgkg}^{-1}\right)$} \\
\hline Ellwan & 7.25 & 3.2 & 0.42 & 0.25 & 1.1 & 0.05 & 0.05 \\
\hline Manghabad & 7.56 & 3.5 & 0.34 & 0.35 & 1.2 & 0.06 & 0.01 \\
\hline Arab-Elmadabegh & 7.11 & 3.7 & 0.52 & 0.38 & 1.0 & 0.08 & 0.03 \\
\hline PL $^{*}$ & & & 0.20 & 0.20 & 5.0 & 0.01 & 0.20 \\
\hline
\end{tabular}

*Permissible limits according to FAO (1985). Each value represents the mean of three replicates. 


\section{Results and Discussion}

Soil and Sewage Wastewater Heavy Metals

Concentrations of $\mathrm{Zn}, \mathrm{Cu}, \mathrm{Pb}$, $\mathrm{Cd}$ and $\mathrm{Ni}$ in the investigated wastewater samples differed from 0.34 to $0.52,0.25$ to $0.38,1.0$ to $1.2,0.05$ to 0.8 and 0.01 to $0.05 \mathrm{mg} \mathrm{L}$, respectively (Table 2). The levels of $\mathrm{Zn}, \mathrm{Cu}$ and $\mathrm{Cd}$ were higher than the permissible limits of the irrigation water according to the FAO (1985). On the other hand, $\mathrm{Pb}$ and $\mathrm{Ni}$ concentrations in these wastewater samples were lower than the FAO (1985) allowable limits. The highest $\mathrm{Zn}, \mathrm{Cu}$ and $\mathrm{Cd}$ concentrations were recorded for Arab-Elmadabegh, where the sewage wastewater collection and treatment station of Assiutcity is located.

The total concentrations of $\mathrm{Zn}$, $\mathrm{Cu}, \mathrm{Pb}, \mathrm{Cd}$ and $\mathrm{Ni}$ in the studied soil samplesvaried from 620 to 640,302 to 310,300 to $305,4.8$ to 6.5 and 120 to $150 \mathrm{mgkg}^{-1}$, respectively (Table 3 ). The total concentrations of the investigated metals $(\mathrm{Zn}, \mathrm{Cu}, \mathrm{Pb}, \mathrm{Ni}$ and $\mathrm{Cd})$ were above the maximum permissible limits recorded by EU (2002) and USEPA (1997). These obtained values confirmed that the soils under study are contaminated with these heavy metals. Similar results were found by Eissa (2016). The long-term use of treated and untreated wastewater in irrigation was reported to cause significant buildup of the heavy metals in the soils (Khan et al., 2008; Ullah et al., 2011; Gosh et al., 2012; Uzma et al., 2016; Zia et al., 2017).

Table 3. Available and total heavy metals concentrations $\left(\mathrm{mgkg}^{-1}\right)$ in the soils of the studied sites

\begin{tabular}{|l|c|c|c|c|c|}
\hline \multirow{2}{*}{ Study site } & \multicolumn{5}{c|}{ DTPA-extractable metal } \\
\cline { 2 - 6 } & Zn & Cu & Pb & Cd & Ni \\
\hline Ellwan & 5.0 & 5.2 & 5.1 & 0.30 & 1.0 \\
\hline Mankhabad & 6.0 & 5.6 & 5.3 & 0.50 & 1.5 \\
\hline Arab-Elmadabegh & 6.9 & 6.5 & 6.8 & 0.40 & 1.9 \\
\hline & \multicolumn{5}{|c|}{ Total metal } \\
\hline Ellwan & 640 & 305 & 304 & 5.4 & 120 \\
\hline Mankhabad & 620 & 302 & 305 & 4.8 & 150 \\
\hline Arab-Elmadabegh & 620 & 310 & 300 & 6.5 & 130 \\
\hline PL $^{*}$ & $200-300$ & $50-140$ & 300 & 3.0 & 50 \\
\hline
\end{tabular}

*Permissible limits according to European Union Standards (EU, 2002) and U.S. Environmental Protection Agency (USEPA, 1997).

Heavy Metals in the Edible Parts of Carrot, Turnip and Onion Plants

\section{Zinc (Zn)}

The concentrations of $\mathrm{Zn}$ in the edible parts of the studied plants ranged between 45 and $70 \mathrm{mgkg}^{-1}$ (Figure 1). The highest Zn concentration was recorded in the edible part of carrot collected from Arab-
Elmadabegh. The soil of ArabElmadabegh contained the highest available level of soil $\mathrm{Zn}\left(6.9 \mathrm{mgkg}^{-}\right.$ $\left.{ }^{1}\right)$. This may explain the highest concentration of $\mathrm{Zn}$ in the plant grown in this soil. Concentrations of $\mathrm{Zn}$ in the edible portions of the studied plants were found to decrease in the order: carrot $>$ turnip $>$ onion. According to 
EU (2006) and WHO/FAO (2007), the maximum permissible $\mathrm{Zn}$ limit for human consumption is between $60-80 \mathrm{mgkg}^{-1}$ dry weights. Thus, the concentrations of $\mathrm{Zn}$ in the current study were less than the allowable level and these plants are safe for human consumption.

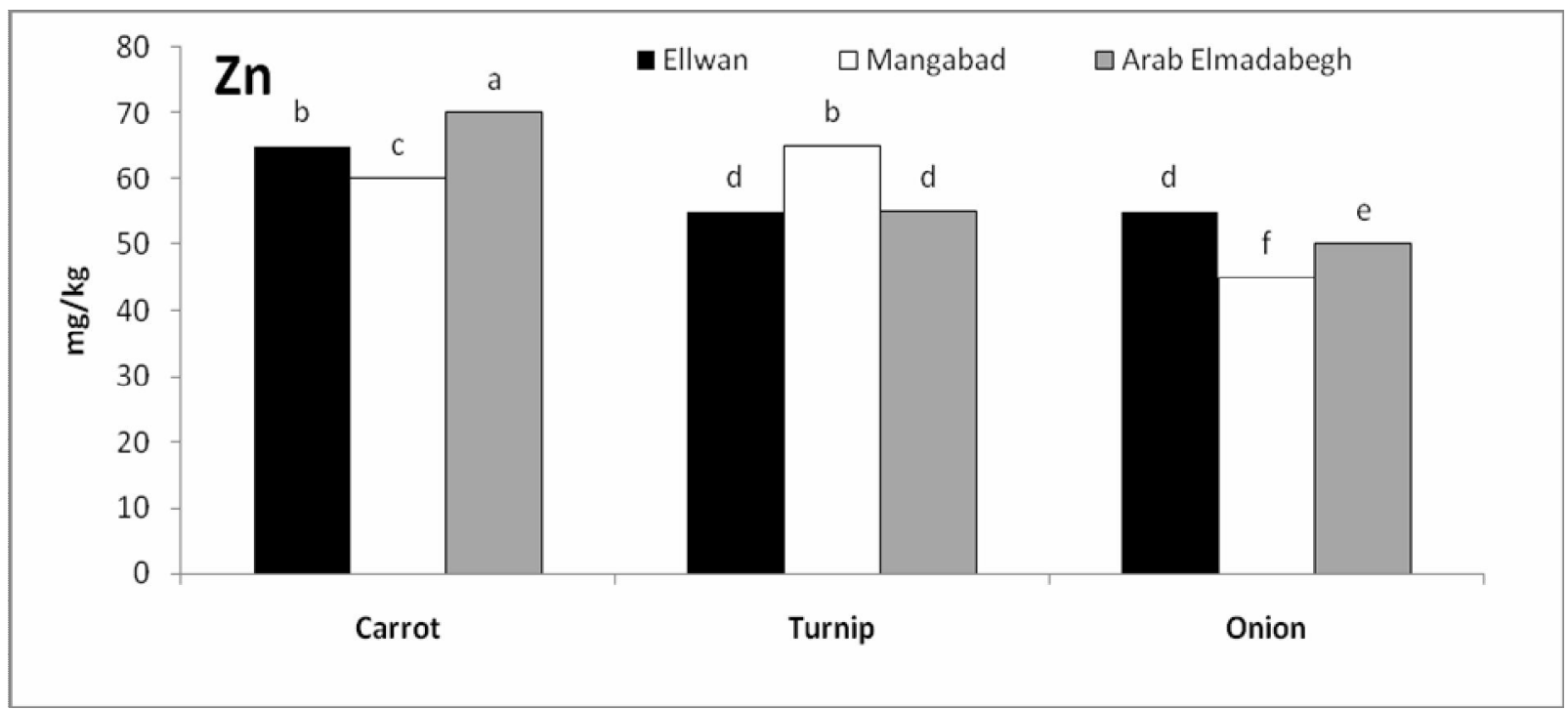

Figure 1. Zinc $(\mathrm{Zn})$ concentrations $\left(\mathrm{mgkg}^{-1}\right)$ in the edible parts of carrot, turnip and onion plants

\section{Copper (Cu)}

The concentrations of $\mathrm{Cu}$ in thein the edible parts of carrot, turnip and onion plants varied from 13 and $19 \mathrm{mgkg}^{-1}$. The highest value of $\mathrm{Cu}$ concentration was recorded for carrot plants grown on the soil of ArabElmadabegh which contained the highest value of the available soil $\mathrm{Cu}$ $\left(6.5 \mathrm{mgkg}^{-1}\right)$.
The edible portions of the studied plants exhibited $\mathrm{Cu}$ concentrations were decresed in the order of: carrot $>$ turnip $>$ onion.

The maximum permissible concentration of $\mathrm{Cu}$ in the edible parts for human consumption is $40 \mathrm{mgkg}^{-1}$ dry weight (EU, 2006; WHO/FAO, 2007). Therefore, the edible parts of these plants are safe to be used by human being.

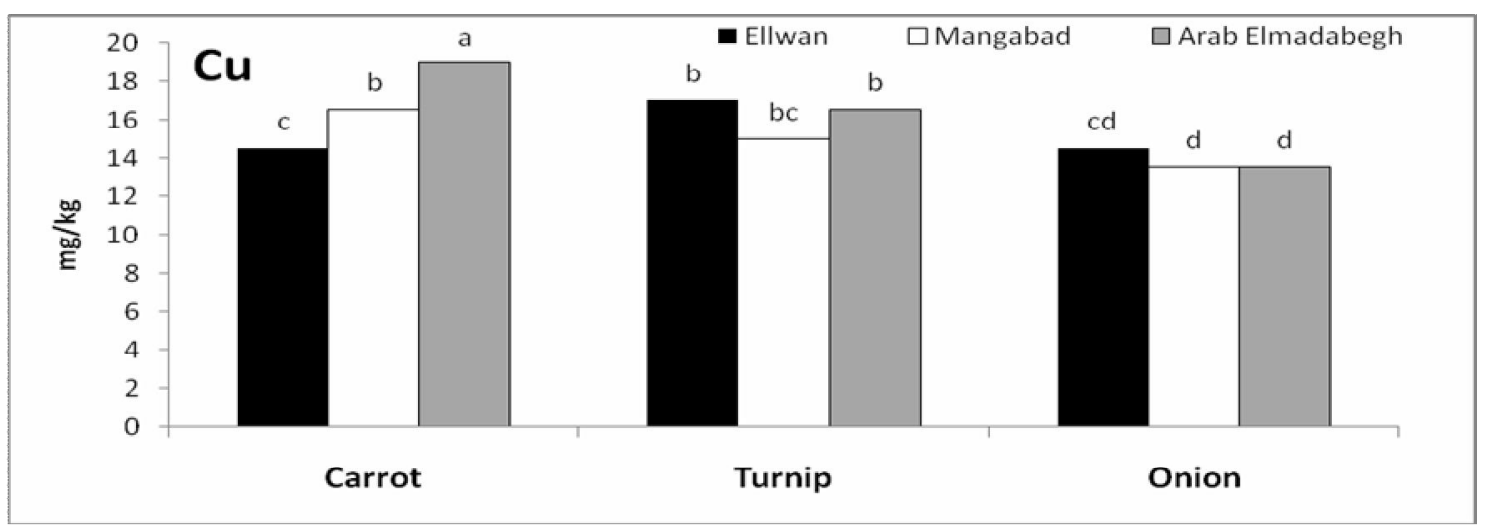

Figure 2. Copper $(\mathrm{Cu})$ concentrations $\left(\mathrm{mgkg}^{-1}\right)$ in the edible parts of carrot, turnip and onion plants 


\section{Lead (Pb)}

The Pbcontent of the edible parts of carrot, turnip and onion plants differed between 3.8 and 6.2 $\mathrm{mgkg}^{-1}$ (Figure 3). According to EU (2006) and WHO/FAO (2007) the maximum Pbpermissible level for human consumption is $0.3 \mathrm{mgkg}^{-1}$ dry weight. Thus, the concentrations of $\mathrm{Pb}$ in the edible plant parts were higher than this permissible level indicating that they are unsafe to be used. The results indicated that sewage wastewater use in irrigating these vegetables caused a significant increase in Pbcontent in their edible portions. These results are in an agreement with those of Rattan et al. (2005) and Ismail et al.(2014). Also, Eissa. (2015) found that the $\mathrm{Pb}$ stored in plant roots was from 93 to $98 \%$ from the total $\mathrm{Pb}$ absorbed by these plant roots. Moreover, Fahr et al. (2013) reported that plant roots can absorb $\mathrm{Pb}$ 3-50 times more than the leaves. This may explain the high levels of $\mathrm{Pb}$ in the roots of turnip, onion and carrot.

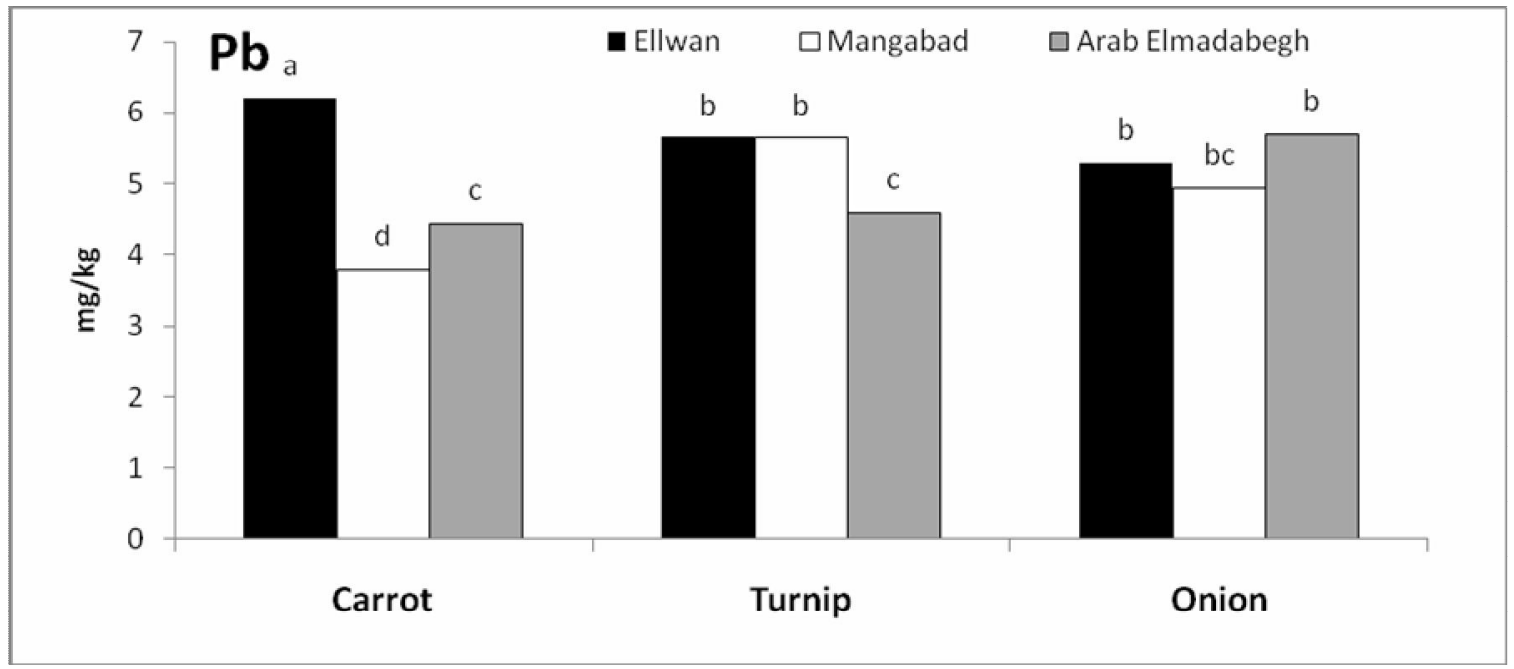

Figure 3. Lead $(\mathrm{Pb})$ concentrations $\left(\mathrm{mgkg}^{-1}\right)$ in the edible parts of carrot, turnip and onion plants

\section{Cadmium (Cd)}

The edible parts of carrot, turnip and onion plants contained $\mathrm{Cd}$ levels varied between 2.85 and $3.85 \mathrm{mgkg}^{-1}$ (Figure 4). EU (2006) and WHO/FAO (2007) indicated that the maximum permissible level of $\mathrm{Cd}$ for human consumption is $0.2 \mathrm{mgkg}^{-1}$ dry weight. Thus, the concentrations of $\mathrm{Cd}$ in theseedible parts were higher than that permissible limit which mean that arenot safe to be consumed. These results coincide with those of Rattan et al. (2005) andIsmail et al. (2014). High concentrations of $\mathrm{Cd}$ in roots of carrot, turnip and onion plants may be related to its low translocation within plants (Voutsa et al., 1996). Similar results were reported by Uzma et al. (2016) and Zia et al. (2017). 


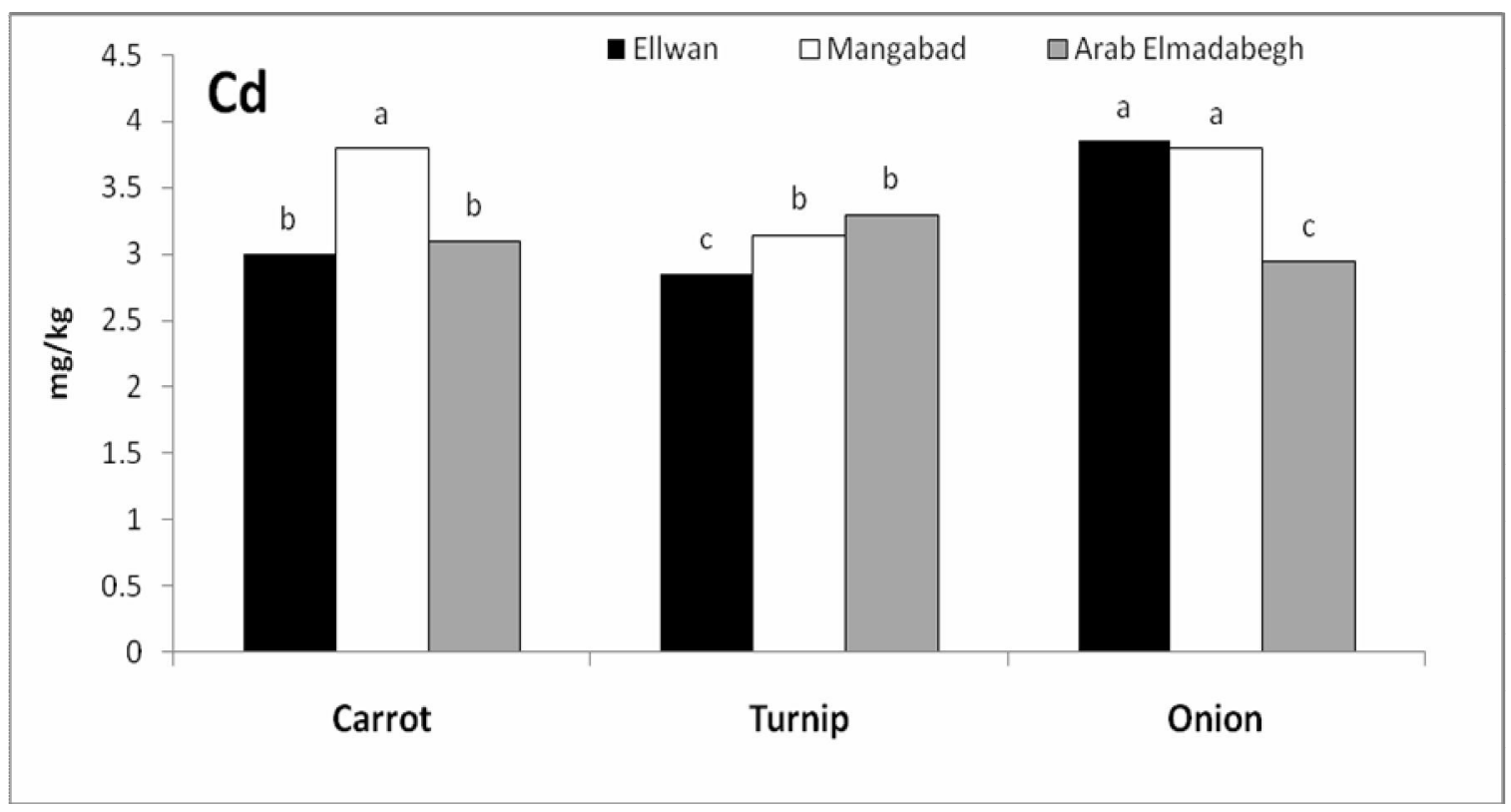

Figure 4. Cadmium $(\mathrm{Cd})$ concentrations $\left(\mathrm{mgkg}^{-1}\right)$ in the edible parts of carrot, turnip and onion plants

\section{Nickel (Ni)}

Nickel (Ni) levels in the edible parts of carrot, turnip and onion plants varied from 2 to $6 \mathrm{mgkg}^{-1}$. The highest level of Ni concentration was recorded in the edible part of carrot plants collected from ArabElmadabegh site. As it shown in Table 2, the soil of Arab-Elmadabegh contained the highest available soil Ni $\left(1.9 \mathrm{mgkg}^{-1}\right)$ it may explain the highest levels of $\mathrm{Ni}$ in the investigated plant grown on such soils, which is the point source of the sewage water.

The maximum permissible $\mathrm{Ni}$ levelfor human consumption is 1.5 $\mathrm{mgkg}^{-1}$ dry weight (EU, 2006 and WHO/FAO, 2007). Thus, levels of $\mathrm{Ni}$ in the edible parts of these plants were higher than its permissible limit level. These results are in the same line with those of Rattan et al. (2005) and Ismail et al. (2014). The prolonged application of treated and untreated wastewatersresults in significant buildup of heavy metals in the soils (Khan et al., 2008; Ullah et al., 2011; Gosh et al., 2012) and grown vegetables and cereals which are subsequently transfer to the food chain causing potential health risk to consumers (Sharma et al., 2006; Singh et al., 2010; Gupta et al., 2011). Heavy metals concentrations in plants grown on wastewater-irrigated soils were reported to be significantly higher than thoth grown on fresh waterirrigated soils (Khan et al., 2008; Singh et al., 2010; Gupta et al., 2011; Zia et al., 2017). 


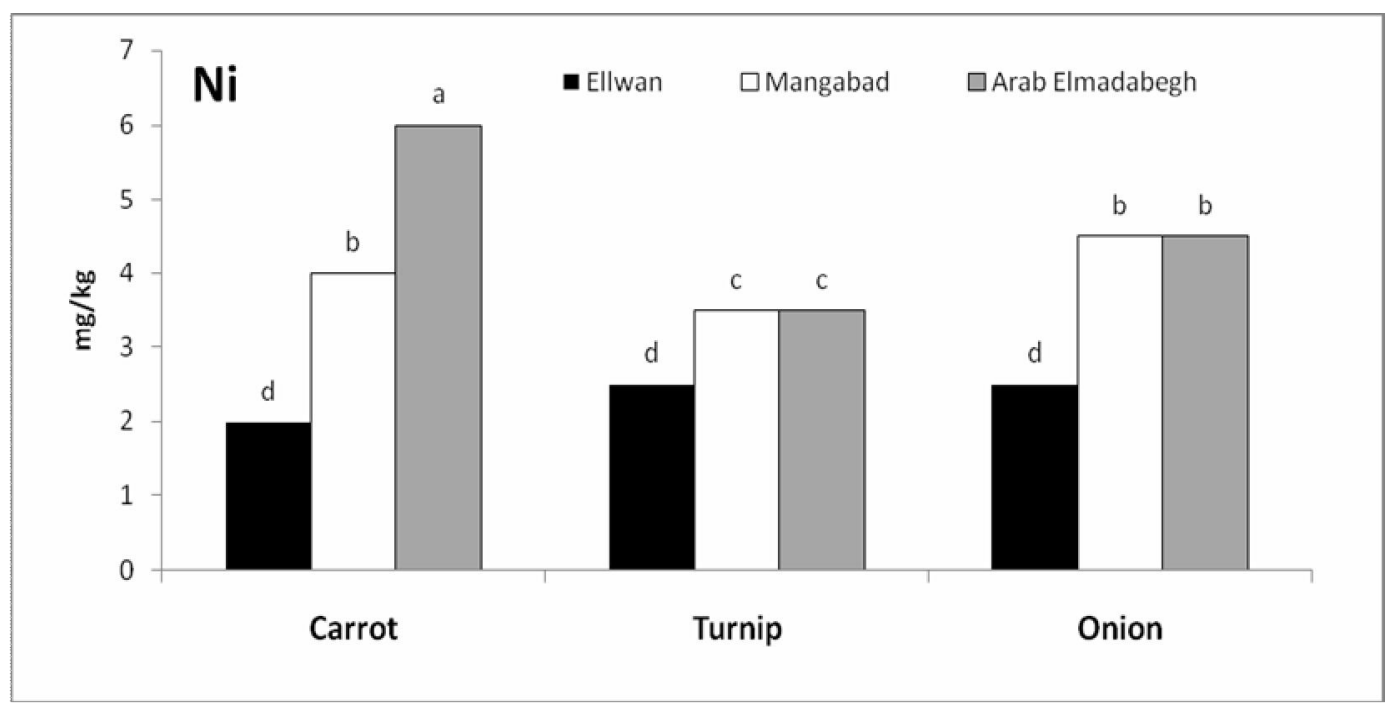

Figure 5. Nickel $(\mathrm{Ni})$ concentrations $\left(\mathrm{mgkg}^{-1}\right)$ in the edible parts of carrot, turnip and onion plants

\section{Conclusion}

It might be concluded that heavy metals could accumulated in the edible vegetables that irrigated withuntreated sewage wastewater. In this study, the obtained results showed that the concentrations of $\mathrm{Pb}$, $\mathrm{Cd}$ and $\mathrm{Ni}$ in the edible parts of carrot, turnip and onion plantswere higher than their permissible limit levels. Therefore, the edible parts of carrot, turnip and onion plants are not safe for human consumption. It is worthy to mention that irrigated edible vegetable crops irrigated with sewage wastewater should be avoided and Egyptian guidelines should be developed for the reuse of these waters in agriculture. Therefore it is recommended to never use sewage wastewaterto irrigate vegetables unless it is obligated. Sewage wastewater might be used to irrigate other plants such as woody trees that can be used as a wind break as well as energy producer plants.

\section{References}

Buchholz, R.A., 1993. Principles of environmental management, in Cliffs, N.J. (Eds.), The Greening of Business. Englewood Prentice Hall, India, pp. 200-220.

Burt, R., 2004. Soil survey laboratory methods manual, second ed. Soil Survey Investigations Report No. 42, Version 4.0, Natural Resources Conservation Service, United States Department of Agriculture, USA.

Chhabra, R., 1989. Sewage water, utilization through forestry, third ed. National Printers, Old Market, West Patel Nagar, New Delhi, India.

Eissa, M. A. 2015. Impact of compost on metals phytostabilization potential of two halophytes species. International Journal of Phytoremediation, 17 (7): 662668, DOI: $10.1080 / 15226514$. 2014.955567.

Eissa M A., 2016. Phosphate and organic amendments for safe production of okra from metalcontaminated soils. Agronomy 
Journal, $\quad 108.2 .: \quad 540-547$. doi:10.2134/agronj2015.0460.

EU., 2002. Heavy Metals in Wastes European Commission on Environment, http: //ec.e uropa.eu/environment/waste/stu dies/pdf/heavy metals report.pdf. (Access on 10 Oct. 2017)

EU., 2006. Commission regulation, EC. No. $1881 / 2006$ of 19 December setting maximum levels for certain contaminants in foodstuffs.Official Journal of European Union L364/5.

Fahr, M., Laplaze, L., Bendaou, N., Hocher, V., Mzibri, M.E., Bogusz, D., Smouni, A. 2013. Effect of lead on root growth. Front Plant Sci 4,175, 1-7. doi:10.3389/fpls.2013.00175.

FAO. 1985. Water quality for agriculture. R.S. Ayers and D.W. Westcot. Irrigation and Drainage Paper 29 Rev. 1. FAO, Rome. $174 \mathrm{p}$.

FAO. 2015. FAOSTAT. Food and Agriculture Organization of the United Nations http://www.fao.org/docrep/005/ y4473e/y4473e08.htm (Access on 1 Oct. 2017).

Ghosh, A.K., Bhatt, M. A., Agrawal, H. P., 2012. Effect of long-term application of treated sewage water on heavy metal accumulation in vegetables grown in northern India. Environ. Monit. Assess., 184, 2.: 1025-1036. https://doi.org/10.1007/s10661011-2018-6.

Gupta, S. K., Scott, C. and Mitra, A., 2011. Advances in Land Resource Management for 21st Century, first ed. Soil Conserva- tion Society of India, New Delhi, India, pp.446-46.

Ismail, A., Riaz, M., Akhtar, S., Ismail, T., Amir, M., Zafar-ulHye, M., 2014. Heavy metals in vegetables and respective soils irrigated by canal, municipal waste and tube well water. Food Additives and Contaminants: Part B Surveillance,7(3), 213219. doi: 10.1080/19393210. 2014.888783.

Kanwar, J. S., Sandha, M. S., 2000. Waste water pollution injury to vegetable crops, a review. Agric. Review., 21, 2.: 133-136.

Khan, S. Q., Zheng, Y. M., Huang, Y.Z., Zhu, Y.G., 2008. Health risks of heavy metals in contaminated soils and food crops irrigated with wastewater in Beijing, China. Environ. Pollution, 152, 3.: 686-692. https://doi.org/10.1016/j.envpol. 2007.06.056.

Khurana, M. P. S., P. Singh., 2012. Waste water use in crop production: A Review. Resources and Environment, 2, 4.: 116-131 DOI: 10.5923/j.re.20120204.01.

Lindsay, W. L., and W.A. Norvell., 1969. Equilibrium relationship of $\mathrm{Zn}^{+2}, \mathrm{Fe}^{3+}, \mathrm{Ca}^{2+}$ and $\mathrm{H}^{+}$with EDTA and DTPA in soils. Soil Sci. Soc. Am. J. 33:62-68. doi:10.2136/sssaj1969.0361599 5003300010020x.

Qadir, M., Sharma, B.R., Bruggeman, A., Choukr-Allah, R., Karajeh, F., 2007. Non-conventional water resources andopportunities for water augmentation to achieve food security in water scarce countries. Agricultural Water Management 87(1), 2-22. 
https://doi.org/10.1016/j.agwat. 2006.03.018.

Rattan, R. K., Datta, S. P., Chhonkar, P. K., Suribabua, K. and Singh, A. K., 2005. Long-term impact of irrigation with sewage effluents on heavy metal content in soils, crops and groundwater-A case study., Agriculture, Ecosystems \& Environ., 109, 31032.

https://doi.org/10.1016/j.agee.20 05.02.025.

Sharma, R.K., Agrawal, M. and Marshall, F. M., 2006. Heavy metal contamination of soil and vegetables in suburban areas of Varanasi, India. Ecotoxicol. Environ. Safety, 66, 2.: 258-266. https://doi.org/10.1016/j.ecoenv. 2005.11.007.

Singh, A., Sharma, R. K., Agrawal, M. and Marshall, F.M., 2010. Health risk assessment of heavy metals via dietary intake of foodstuffs from the wastewater irrigated site of a dry tropical area of India. Food Chem. Toxicol., 48, 2.: 611- 619 . https://doi.org/10.1016/j.fct.200 9.11.041

Ullah, H., Khan, I. and Ullah, I., 2011. Impact of sewage contaminated water on soil, vegetables and underground water of peri-urban Peshawar, Pakistan. Environ. Monit. Assess. 184 (10), 6411-6421. DOI: https:// doi.org/10.1007/s10661-0112429-4

US EPA., 1996. United States Environmental Protection Agency.
Method 3050B. Acid digestion of sediments, sludges, and soils. USEPA; 1996.

Uzma, S., Azizullah, A., Bibi, R., Nabeela, F., Muhammad, U., Ali, I., Rehman, Z., Häder, D.P., 2016. Effects of industrialwastewater on growth and biomass production in commonlygrown vegetables. Environmental Monitoring andAssessment, 188, 1-13. DOI https://doi.org/10.1007/s10661016-5338-8.

Voutsa D., Grimanis A., Samara C., 1996. Trace elements in vegetables grown in an industrial area in relation to soil and air particulate matter, J. Environmental Pollution, 94, 34., p. 325-335. https://doi.org/10.1016/S02697491(96)00088-7.

WHO/FAO., 2007. Joint FAO/WHO Food Standard Programme Codex Alimentarius Commission $13^{\text {th }}$ Session. Report of the Thirty Eight Session of the Codex Committee on Food Hygiene. Houston, United States of America, ALINORM 07/30/13.

Zia, M.H., Watts, M.J., Niaz, A., Daniel, R.S. Middleton, S, Kim, W., 2017. Health risk assessment of potentially harmful elements and dietary minerals from vegetables irrigated with untreated wastewater, Pakistan. Environ Geochem Health, 39: 707.https://doi.org/10.1007/s106 53-016-9841-1. 
تراكم العناصر الثقيلة فى الجزء المأكول لبعض محاصيل الخضر المروية بمياه الصرف الصحى

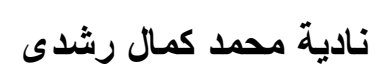

قسم الار اضى و المياه - كلية الزر اعة - جامعة اسيوط

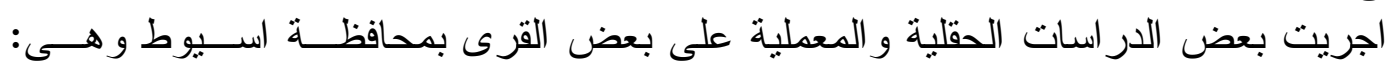

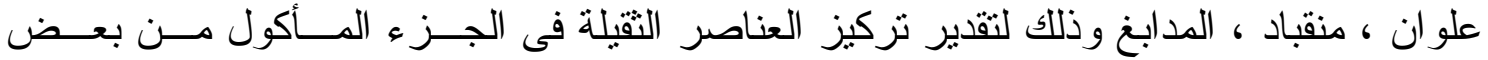

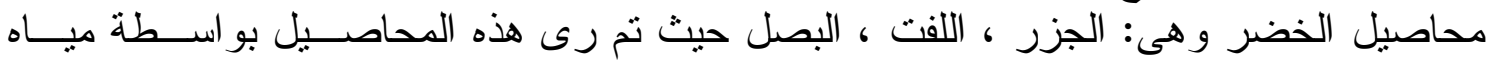

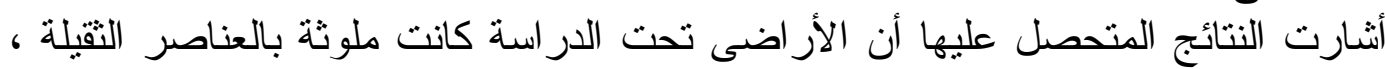

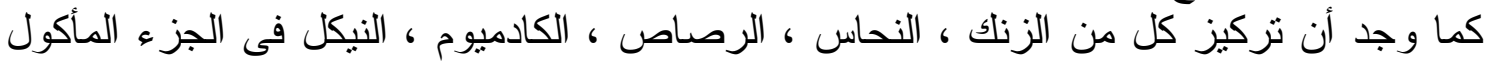

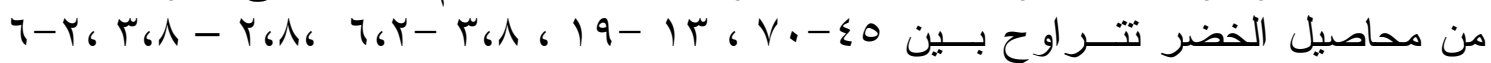

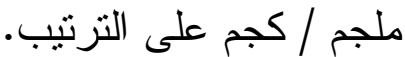

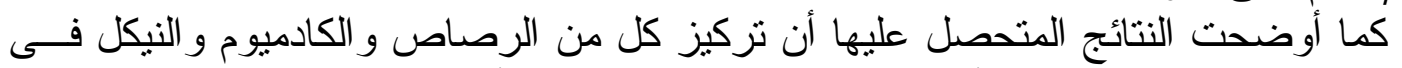

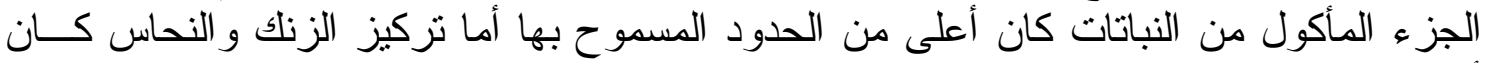

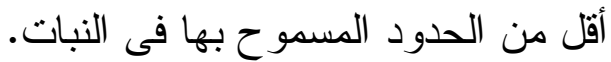

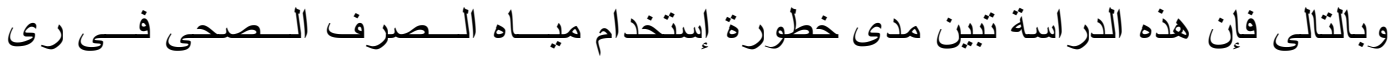

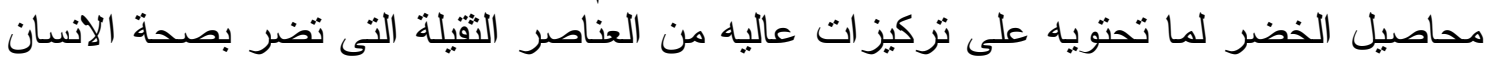

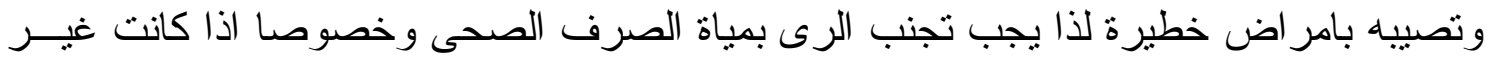
معالجة للمحاصيل التى تدخل فى السلسلة الغذائية للانسان او الحيو النيان. 